\title{
TID TIL IKKE AT TALE OM FORSKEL
}

\author{
Richard Jenkins
}

I løbet af de seneste ca. ti år er identitet blevet et så centralt begreb inden for sociologien og dertil knyttede discipliner, at det med rimelighed kan siges at være et af de vigtigste redskaber i nutidens samfundsvidenskabelige værktøjskasse. Sådan skal det også være. Identitet er af flere grunde et uundværligt og strategisk sociologisk begreb.

Fx ville det faktisk være umuligt at arbejde sociologisk eller med beslægtede discipliner uden at tale om identitet. Vi ville ikke kunne fungere i hverdagen, hvis ikke vi havde en fornemmelse for, hvem vore medmennesker og samtidige er og hvem vi selv er. Af stort set samme grunde ville vi ikke systematisk kunne forstå hverdagen og den menneskelige verden - en forståelse, sociologi efter min mening netop omhandler - hvis vi ikke vidste, hvem der er hvem, og hvilken betydning dette har i en given kontekst. Hvad enten vi taler om køn, klasse, etnicitet, alder, lokalitet, seksualitet eller individualitet - ligegyldigt hvad - så taler vi på den ene eller anden måde om identifikationsprocesser. Vi bør derfor lære at forstå, hvad identitet er, og hvordan den virker i stedet for at tage identitet for givet.

For det andet er identitet et af de meget få begreber, der bygger bro over den akavede begrebskløft mellem individet og det kollektive eller sociale, mellem et mikro- og et makroperspektiv. Hvordan dette forhold skal forstås, er et af de helt centrale samfundsteoretiske spørgsmål. Det lyder umiddelbart fornuftigt at tilskrive individer og kollektiver identitet eller identiteter. Denne brobygning gælder derimod ikke begreber som for eksempel bevidsthed, handlen, praksis eller struktur - begreber, der kræver en betragtelig klassifikation og definition, og som i diskussionen forårsager en del kontroverser, hvis de skal kunne bruges både kollektivt og individuelt.

For det tredje er begrebet identitet anerkendt og anvendt inden for en række beslægtede, intellektuelle diskurser. Sociologi, socialantropologi, socialpsykologi, mikrogeografi, filosofi og kulturstudier - for blot at nævne nogle få - anvender gensidigt forståelige, om end undertiden helt forskellige diskurser, hvad angår identitet. Til tider kan vi mene noget ret forskelligt med det eller have forskelligt syn på det, men vi kan tale meningsfuldt med hinanden om identitet.

Endelig kan vi også uden for de akademiske kredse tale om identitet. Begrebet identitet er gængs og udbredt i daglig tale. Desuden tales der i dag af uvisse årsager meget mere om identitet i dagligdagens sociale sammenhænge end nogensinde tidligere. For lige at vende tilbage til, hvad jeg før sagde om individet og kollektivet og mikro og makro, så giver det at tale om identitet mulighed for med C. Wright Mills’ berømte formulering at forstå historie og biografi - to vedvarende diskussionsemner - på en sådan måde, at hver især indgår i den andens kontekst. Det drejer sig ikke alene om hverdagslivets forhåndsviden: For at blive ved Mills, denne gang ved hans sidestilling af 
private problemer og offentlige anliggender, så beskæftiger politik, ideologi og den politik, der føres i den moderne verden, sig imidlertid også og i lige så høj grad med identitet og identitetsrelaterede spørgsmål.

Spørgsmålet om identitet er tilstrækkeligt vigtig til, at vi ikke kan komme uden om det, hvis vi skal prøve at forstå den menneskelige verden. At tale om identitet og identiteter på den ene eller anden måde er ikke et valgfrit supplement til sociologien. Derfor og især for at kunne kommunikere med offentligheden - er det afgørende, at vi forstår, hvordan identitet virker, og forstår, hvad vi mener, når vi bruger ordet.

Som efterskrift og især, fordi identitet ikke er et begreb, der er begrænset til samfundsvidenskabelige diskurser, er det vigtigt - i forlængelse af, hvad Zygmunt Bauman $(1990,12)$ har identificeret som ‘den ansvarlige tales' sociologiske nødvendighed - at understrege det afgørende ved at tale om identitet på en sådan måde, at det i størst muligt omfang tilpasses de observerbare realiteter i den sociale verden. Dette er det samme som uforbeholdent at argumentere for en hverdagsrealisme som den grundlæggende epistemologiske holdning inden for sociologi og lignende discipliner. Vi er alle en slags realister, når vi færdes i vor hverdag. Dette gælder imidlertid også, når vi foretager samfundsvidenskabelig forskning af forskellig art. At forske betyder nødvendigvis, at man går ud fra, at der er noget at finde 'derude', at det er muligt at finde frem til et eller andet om det, og at det derefter er muligt at forsvare det, som man har fundet frem til, som mere eller mindre plausibelt.

At plædere for konstruktivisme og at tage afstand fra essentialistiske opfattelser af identitet - og jeg gør begge dele i denne artikel - er ikke det samme som at opgive en skelnen mellem, hvad der er sandt eller virkeligt, og hvad der ikke er. Det er heller ikke at slække på proceduren for udførelse af systematiske undersøgelser, som tillader, at vore sociologiske udsagn bliver retfærdiggjort som sandheder (om end kun som betingede sandheder og ikke som evige sandheder). Det drejer sig heller ikke om forskellige former for sociologi: Det gælder overalt både m.h.t. det kvalitative og det kvantitative. Hvis vi forventer, at en identitetens sociologi skal være andet og mere end enten popsmarte almenheder eller underholdende spekulationer, findes der ikke noget alternativ til den moderate hverdagsrealisme, som nødvendigvis, uanset om den anerkendes eller ej, er grundlaget for enhver systematisk sociologisk undersøgelse.

I resten at denne artikel vil jeg argumentere imod en for tiden dominerende identitetsmodel, hvormed det hævdes, at identitet stort set eller nærmest udelukkende er et spørgsmål om forskelle og forskelles betydning. Jeg har tre forbehold. For det første gør et fokus på forskel det umuligt at forstå, hvad identitet er, og hvordan identitet virker. For det andet er et fokus på forskel et frontalangreb på hverdagslivets observerbare realiteter. For det tredje gør et fokus på forskel det umuligt at beskæftige sig med de væsentligste spørgsmål inden for samfundsteori eller måske umuligt overhovedet at anvende samfundsteori.

1. Hvilken identitetsmodel er det, jeg argumenterer imod? 
Noget af det første, som man skal lægge mærke til, er, at denne identifikationssmodel ikke repræsenterer en bestemt skoles tænkning. Den består af et sæt argumenter og holdninger i generel overensstemmelse med hinanden, som har deres rødder i en række debatter, der har fundet sted i løbet af de seneste par årtier. En af disse debatter handlede - over et bredt og heterogent intellektuelt spektrum - om teoretiske alternativer til strukturalismen. Her blev inspirationen især hentet i fx Derridas begreb différance og i psykoanalytiske modeller, som betragtede identifikation som en proces, hvor der sker en opsplitning af og en afsondring fra egoets tidligste signifikante anden/andre.

Der er også blevet sagt meget om forskel i skikkelse af diverse postmodernistiske fortolkninger. Her har betoningen af forskel været en del af opgøret med de store fortællinger og den moderne universalisme samt en anerkendelse af forskellige holdninger til og forståelser af den sociale verden.

Rekonstruktionen af samfundsteori og politisk strategi på den brede venstrefløj som følge af statssocialismens sammenbrud i Europa og den højredrejning, der fandt sted i de vestlige socialt bevidste demokratier - har også haft stor betydning. En måske, måske ikke, kynisk strategi til at danne nye politiske alliancer kom til udtryk i ideer som 'regnbuekoalition' og 'identitetspolitik', hvor 'forskel' var et gennemgående tema. Noget, der også har haft betydning, om end helt uafhængigt heraf, er kampagner ført af en række interessegrupper og bevægelser - fx kvinder, etniske minoriteter, bøsser og lesbiske, handicappede - der har forfægtet det positive ved mangfoldighed og forskel og den etiske og politiske fordel ved pluralisme. Med Charles Taylors tankevækkende formulering kaldes dette 'anerkendelsespolitik'.

Blandt forfattere i Storbritanien, hvis værker har fokuseret på undersøgelse og betoning af forskel, finder man Avtar Brah, Paul Gilroy, Stuart Hall, Jeffrey Weeks, Floya Anthias og Fiona Williams. Set i et bredere perspektiv kan nævnes indflydelsen fra så øjensynligt forskellige filosoffer og teoretikere som Charles Taylor, Luce Irigaray, Seyla Benhabib, Steven Seidman og Judith Butler. Som man måske har kunnet forvente, har argumenterne og debatten om forskel været præget af mange forskellige tilgange og perspektiver.

Centrale elementer i denne brede opfattelse af identitet er fuldstændig korrekte, $\mathrm{fx}$ dens antiessentialisme. At hævde, at identitet hverken er fast, uforanderlig eller oprindelig, at det snarere end at være 'naturligt' på en eller anden måde udspringer fra noget yderst socialt, og at det kan diskuteres og tilpasses omstændighederne, er for mig at se det rigtige udgangspunkt, hvis vi skal forstå, hvad identitet er, og hvordan identifikationssprocesser virker. Dette synspunkt er dog hverken nyt eller originalt. Det har især haft stor indflydelse i den seneste socialantropologi efter Fredrik Barth (1969), men det har endnu dybere sociologiske rødder, som strækker sig tilbage til Goffman, over Hughes, frem til Weber og Simmel (Jenkins 1996). Teoretikere har i de senere år i bedste fald genopfundet dette specielle synspunkt.

Noget andet, som også stemmer overens med den holdning, jeg er fortaler for, og som præger nogle af de nævnte forfatteres argumenter, er en velbegrundet mistillid til den universalisme, som indbefatter ligestillet borgerskab. Amy Gutmann beskriver i sin 
introduktion til Charles Taylors essay om 'The Politics of Recognition’ universalismen som 'totalitær' (1994, 7), og Luce Irigaray siger det således: “'supposedly universal values' turn out to entail one part of humanity having a hold on the other” (1993, 16, hendes fremhævelse). Disse synspunkter er vigtige og kan forsvares: Der er vigtige og svære spørgsmål, som skal stilles om tvungen integration, integration på hvis betingelser osv. De senere års fremherskende politik i Storbritanien, der afspejler Det Ny Labours grundholdning til integration i samfundet, er en provokerende illustration af nogle af de problemer, der følger i kølvandet på en universalisme. At det er værdifuldt, endog nødvendigt med mangfoldighed og forskel, er en politisk holdning, som denne artikels argumenter ikke underminerer.

Når det er sagt, er der dog to andre centrale påstande, som er i tråd med ovennævnte forfatteres argumenter, som jeg på det kraftigste vil tage afstand fra. Ifølge den første påstand handler identifikation primært om at finde og påpege forskelle blandt mennesker. Selv i de diskussioner, hvor identitet accepteres som noget, der handler om, for igen at citere Bauman (1992) 'tale-om-os' - om integration og tilhørsforhold - opnås dette tilsyneladende gennem forskel fra og udelukkelse af andre. Stuart Hall har sammenfattet dette synspunkt med særlig klarhed:

[identities] are more the product of the marking of difference and exclusion, than they are the sign of an identical, naturally-constituted unity - an identity in its traditional meaning (that is, an all-inclusive sameness, seamless, without internal differentiation).

Above all, and directly contrary to the form in which they are constantly invoked, identities are constructed through, not outside, difference. This entails the radically disturbing recognition that it is only through the relation to the Other, the reaction to what it is not, to precisely what it lacks ... that the positive meaning of any term - and thus its 'identity' - can be constructed ... identities can function as points of identification and attachment only because of their capacity to exclude. (Hall 1996, 4f)

At identificere mig selv er således et spørgsmål om at skille mig ud fra og distancere mig fra dig og dig og fra den person derovre. At identificere 'os' afhænger af, at vi ikke er ‘dem’ osv. Seyla Benhabib (1996, 3) har sagt noget lignende:

Since every search for identity includes differentiating oneself from what one is not, identity politics is always and necessarily a politics of the creation of difference - [hun taler så om bosniske serbere og ekstreme zionistiske israelere] - What is shocking about these developments is not the inevitable dialectic of identity/difference that they display, but rather the atavistic belief that identities can only be maintained and secured by eliminating difference and otherness.

Læg mærke til brugen af ord som ‘always’ og ‘inevitable’. Mens identitet i Benhabibs version konstrueres ud af og i takt med differentiering, synes identitet og forskel ikke at være det samme. I de udtryk, som jeg netop har brugt, handler identitet om mig/os, mens forskel handler om dig/dem. Identifikation med og differentiering fra er forskelli- 
ge processer, hvor den ene (differentiering) tillader den anden (identifikation) at finde sted.

Over et bredt spektrum af litteratur fra avancerede teoretiske debatter til indførende lærebøger er forskel blevet anset for at være en så selvfølgelig ting i forbindelse med identifikation, at det næsten nogle gange synes at være blevet det vigtigste emne inden for de 'samfundvidenskabelige discipliner'. 'Forskelsparadigmet', som jeg skitserer her, er hverken en stråmand eller en af mange vindmøller, der skal bekæmpes. Fx stammer følgende fra indledningen til en central tekst i socialpolitik ved Open University i Storbritanien:

How we view the conditions and consequences of social policies depends very heavily on how we understand the society in which such policies are formulated and implemented. At the centre of this problem is the question of how we make sense of patterns of difference between individuals and groups in society. We might ask a number of questions about the issues of difference:

- What sorts of differences are visible in our society?

What sorts of differences have consequences in our society?

What do we do about such differences?

Where do these differences come from?

(Clarke and Saraga 1998, 1, min fremhævelse)

Det ser næsten ud som om, at forskel er blevet det princip, ud fra hvilket man definerer kollektivitet og den menneskelige verden, det punkt, som alt andet drejer sig om.

Den anden almindelige påstand, som jeg ønsker at tage afstand fra, er, at identitet i det seneste årti eller to er blevet betydningsfuld i en sådan grad, at politik i de vestlige demokratier og især globalt er blevet 'identitetspolitik'. Denne påstand finder typisk empirisk støtte eller retfærdiggørelse på et utal af steder: I den klasseløse politiks og de sociale bevægelsers vitalitet og indflydelse, jf. feminisme, handicapbevægelsen, etniske minoriteters borgerrettighedsbevægelser, grønne bevægelser med diverse dybder og nuancer, bøssers og lesbiskes aktivisme og nationalisme; i massive postkoloniale diasporaers globale, kulturelle og politiske indflydelse, som har resulteret i stadig mere heterogene befolkninger, kulturelt og etnisk; i den tilsyneladende fremkomst af transnationale identifikationsfællesskaber; i forfaldet hos, for ikke at sige nederlaget for en politik baseret på solidaritet og organisering af arbejderklasserne; og i forbrugersamfundets udbygning af alternative livsstilsformer. For igen at citere Stuart Hall: "cultural diversity is increasingly the fate of the modern world..” $(1992,8)$

Med et endnu bredere syn på de identiteter, der står på spil, har Kathryn Woodward i en anden Open University tekst (Woodward 1997, 1) argumenteret for, at:

old certainties no longer obtain and social, political and economic changes both globally and locally have led to the breakdown of previously stable group membership. Identities in the contemporary world derive from a multitude of sources - from nationality, ethnicity, social class, community, gender, sexuality - sources which may conflict in the construction of identity positions and lead to contradictory fragmentary identities. 
Både hos Hall og Woodward ligger vægten på denne 'identitetssnaks’ særprægede, seneste mode. 'Bøsseteori', der opstår ud af en sammenblanding af samfundsteori, litteratur- og kunstkritik og lesbiskes og bøssers aktivisme, repræsenterer måske den mest udtalte intellektuelle version af denne position, ligesom den i sig selv er en manifestation af dette åbenbare skift i politiske emner (fx Butler 1990; Seidman 1997).

Dette er således de to vigtigste påstande i 'forskelsparadigmet', som jeg vil tage fat på: For det første, at identifikation primært handler om forskel; og for det andet, at betydningen af identitet-i-mangfoldighed er et nyere fænomen i menneskers dagligliv. Begge disse påstande kan tilbagevises. De er ikke blot omdiskuterede, men forkerte. For at vende tilbage til de tre forbehold, som jeg skitserede tidligere, vil jeg nu undersøge deres indvirkning på disse påstande.

\section{Første forbehold}

Man kunne hævde, at et fokus på forskel gør det umuligt at forstå, hvad identitet er, og hvordan identifikationssprocesser virker. Hvorfor skulle dette være tilfældet? Det grundlæggende synspunkt er ganske enkelt, at identitet indbefatter mere end blot forskel (Jenkins 1996, 3-5). Et opslag i ordbogen hjælper til en klarere forståelse af dette. Ordet stammer fra latin (identitas, fra idem, 'det samme') og har to grundlæggende betydninger: Ensartethed (noget er identisk med noget andet) og kontinuitet over tid - ensartethed igen - som fremhæver individualitet og særegenhed. Identitetsbegrebet skaber således samtidigt to mulige sammenligningsforhold mellem mennesker og/eller ting: Lighed og forskel. Hvis man udbygger dette, betyder det afledte verbum 'at identificere' også to ting: At identificere sig selv med noget eller nogen og at identificere mennesker eller ting. Det første, en slags association, fremkalder en idé om lighed; det andet, klassifikation, involverer nødvendigvis både lighed og forskel.

Begrebet identitet refererer således til de måder, hvorpå individer og kollektiver udskiller sig fra andre individer og kollektiver i deres sociale relationer. Dette er den systematiske etablering og betydning af ligheds- og forskelsrelationer blandt individer, blandt kollektiver og blandt individer og kollektiver. Lighed og forskel som identitetens dynamiske principper er helt centrale i den menneskelige verden.

Ligesom de fleste ideer, som denne artikel forholder sig til, er dette ikke noget nyt. I 1844 skrev Marx følgende i et brev til Feuerbach: "The unity of man with man, which is based on the real differences between men, - what is this but the concept of society!" (citeret i Wheen 1999, 55). Og mere end halvfjerds år senere lyder det i en meget lignende vending hos Simmel:

Similarity as fact or tendency is no less important than difference - both are the great principles of all internal and external development. In fact the cultural history of mankind can be conceived as the history of the struggles and conciliatory attempts between the two. $(1950,30)$ 
Det er interessant, at nogle af de forfattere, imod hvis understregning af forskel jeg argumenterer, synes at anerkende i det mindste noget af det nødvendige samspil mellem lighed og forskel. Hertil hører fx Paul Gilroy:

identity is always particular, as much about difference as about shared belonging ... identity can help us to comprehend the formation of the fateful pronoun 'we' and to reckon with the patterns of inclusion and exclusion that it cannnot help but to create. This may be one of the most troubling aspects of all: the fact that the formation of every 'we' must leave out or exclude a 'they', that identities depend on the marking of difference. (1997, 301f)

Mens uenigheden mellem os synes et spørgsmål om, hvad vi lægger vægt på, tilskriver Gilroy dog stadig forskel et analytisk privilegium som det aktive princip i de markeringer, som identifikation afhænger af. I modsætning hertil argumenterer jeg for, at det hverken logisk set eller i den almindelige dagligdags processer ikke giver mening at adskille lighed og forskel eller at tilskrive det ene forrang. Man kan ganske enkelt ikke have det ene uden det andet. At identificere noget som A indebærer, at man hævder, at det har visse egenskaber tilfælles med alle andre A'er, og at det er forskellig fra B'er, C’er osv. At sige, hvem jeg er, er at sige, hvem eller hvad jeg ikke er, men det er også at sige, hvem jeg har noget tilfælles med.

Der er for eksempel ingen tvivl om, at ens personlige navn er markør for individuel forskel. Faktisk er det en af de afgørende markører for individuel forskel. Men at benævne sig selv er normalt også at fastsætte sit offentlige, sociale køn. For dem med tilstrækkeligt kontekstuelt kendskab kan det også placere én i forhold til familie- eller slægtskab. Andet lokalt kendskab gør det måske muligt at fastslå éns etnicitet eller religion eller begge som i Israel eller Nordirland. Mens éns navn således udtrykker individuel særegenhed, placerer det også én med hensyn til kollektive ligheder (og naturligvis forskelle).

Dette indebærer en yderligere drejning. Hvis det var muligt at påvise individuel eller kollektiv forskel uden samtidig at fremføre nogle fælles træk med andre, så ville dette logisk og socialt - kun formidle, hvad man ikke er. Med mindre man udtømmende kunne benægte den række af alle andre muligheder for, hvem man kunne være - undtagen én naturligvis - ville dette ikke være tilstrækkelig til at formidle, hvad man er. Forskel alene er ganske enkelt ikke nok. Det er også usandsynligt, ja, endda på nippet til at være utænkeligt.

Et svar på denne kritik kunne være at argumentere for, at det er begrebet identitet - i modsætning til forskel - der behandler spørgsmålet om lighed. Dette syn på sagen kan føres helt tilbage til Locke. Det er fx underforstået i det tidligere citat fra Seyla Benhabib, og det er den tilgang, man har valgt i Open University lærebogen Identity and Difference, redigeret af Kathryn Woodward (1997). Floya Anthias synes også at have dette in mente i sin seneste kritiske gentænkning af, hvorvidt forskelsbegrebet kan bruges til forståelse af sociale skel (1998). Hun taler om identifikation og differentiering som separate, men forbundne sociale processer. David Taylor påstår noget lignende i en 
artikel om identitet og socialpolitik, hvor han taler om, at "the incorrect assumption that 'difference' and 'identity' are in some way the same thing” (1998, 340). Taylor uddyber denne holdning nærmere, idet han synes at argumentere for, at forskel handler om individualitet, mens identitet (ensartethed) handler om kollektivitet.

Denne løsning dækker imidlertid af to grunde ikke helt det, jeg vil sige. For det første går den imod det, som mange af disse forfattere faktisk siger. Fx Stuart Hall er helt klar over, at han ikke beskæftiger sig med identitet i traditionel forstand (dvs. en altomfattende ensartethed uden intern differentiering). Han bruger snarere en model for identifikation og tilknytning - i dette tilfælde afledt af en social læsning af psykoanalysen som helt afhænger af en udelukkelse af andre, en etablering af forskel. Uanset, hvad man måtte have at sige om anvendeligheden af modeller angående sociale processer udledt fra psykoanalysen, er vægtlægningen på forskel og forskel alene ikke til at tage fejl af. At lighed også har en betydning, kommer end ikke ind i billedet.

Det andet - og væsentligere - problem er, at man ved at isolere identifikationsprocesser fra differentieringsprocesser privilegerer én af de betydninger af identifikation, som jeg skitserede tidligere, nemlig identifikation med noget. Ved at gøre dette står identitet i fare for at blive ensbetydende med konformite om ikke direkte konformisme. Judith Butler synes for eksempel kun at forstå identitet som subjektiv konformisme og tilknytning og det til trods for, at hendes modstand mod de universalistiske identiteters potentielle tyranni netop afhænger af en værdsættelse af den pålagte klassifikationsmagt. Butlers argument for nødvendigvis at måtte nedbryde og transcendere identitet - eller hvad hun snarere ser som illusionen eller fælden ved identitet - i sit forsøg på at frigøre forskel bunder i en kritisk forståelse af "the presumption that identities are selfidentical, persisting through time as the same, unified and internally coherent” (Butler 1960, 16). Ligheden med Stuart Halls synspunkt citeret ovenfor er slående.

Det er alene hendes forståelse af identitet og forskel som aldeles adskilt fra hinanden og af identitet som identifikation med noget, der tillader Butler den luksus overhovedet at forestille sig muligheden af at transcendere identitet. Ved at lægge vægten på 'identifikation med’ overses den kendsgerning, at identifikation også er et spørgsmål om at klassificere - dvs. at etablere - andres identitet og især éns egen, og at klassifikation virker gennem en kombination af ligheder (ligesom mig, ligesom os) og forskelle (ikke ligesom mig, ikke ligesom dem). Over for de mest yderliggående muligheder, der foreslås af Butler, synes absolut differentiering fra andre - mindst lige så vel som absolut indoptagelse af andre - at være en meget sjælden fugl (der, for at fortsætte metaforen, ikke kan flyve, og som er i konstant fare for at uddø).

Hvis identitet, som jeg foreslår, må tilskrives både lighed og forskel, vil identifikationsprocessen lige så nødvendigt involvere etableringen af begge. Rutinemæssigt fremkalder både individuelle og kollektive identifikationsprocesser såvel lighed som forskel. Disse er derudover vedvarende, åbne processer, hvor en dialektisk model sandsynligvis i store træk vil kunne bruges som forklaring og præsentation, men hvor de i det daglige liv og i den daglige praksis viser alle tegn på samtidighed. Det er ikke 'forskel, så lighed', mere end det lige så godt kunne være 'lighed, så forskel'. 
Mit argument har indtil nu været, at identitet fremkalder lighed og forskel på samme tid. Identifikation involverer klassifikations- og betydningsprocesser, der nødvendigvis trækker på begge aspekter. Forskel alene, eller blot en laggen væegt på forskel, er ikke nok til at forklare, hvad identitet er, og hvordan identifikationsprocesser virker. For ikke at misforstås, er det imidlertid vigtigt at understrege, at jeg ikke hentyder til nogen objektivt set korrekt betydning af lighed eller forskel. Det, jeg taler om, er det, som mennesker, der er engageret $\mathrm{i}$ identifikation af selvet og af andre, lagger $i$ identitet - i lighed og forskel. Butler har i denne henseende ret, når hun afviser identifikationens tillokkende illusioner. De er konstruktioner, forestillinger helt igennem. Når det er sagt, vil jeg gå videre - på en mulig (men kun tilsyneladende) paradoksal vis - til mit andet forbehold over for forskelsmodellen for identitet.

\section{Andet forbehold}

Et fokus på forskel er et frontalangreb på hverdagslivets observerbare realiteter. Jeg har allerede været temmelig provokerende ved at argumentere for, at identitet i hverdagslivet ikke kun, ja, end ikke overvejende, handler om forskel eller mangfoldighed. Det handler også om lighed og solidaritet. Det handler også om tilhørsforhold, om fællesskab. Det handler i det store og hele om 'os' og 'vi'.

Ord som os, vi, fællesskab og solidaritet bør naturligvis alle være forsynet med en advarsel. De er dybt politiske, og man skal være på vagt over for dem og de mennesker, der ynder at bruge dem. Her bør man erindre sig Charles Taylors - eller sågar fra en anden kant, Judith Butlers - argumenter for de farer, der ligger i 'identitet som ensartethed' (og deres respektive argumenter for, at det er elementært nødvendigt for demokratiet at anerkende forskel eller forskellens tiltagende subversive karakter). Man bør også huske på Samuel Johnsons karakteristik af patriotisme som skurkens sidste tilflugtssted. Enhver, som har fulgt med i britiske og amerikanske politiske debatter i de seneste år, vil måske sige det samme om fællesskab (for ikke at glemme integration).

Disse begreber er naturligvis udtænkte. Med Anthony Cohens ord er de 'symbolske konstruktioner' (1985). Men de er utroligt stærke forestillinger, som folk handler i overensstemmelse med. Selv hvis de er forestillede, er de alt andet end imaginære: De er af stor betydning i den sociale verden (Jenkins 1996). Solidaritet kan, når den først er fremmanet med succes, have en meget markant tilstedeværelse i verden.

Og disse vi-ord, der påkalder lighed, er naturligvis tæt knyttet til fremmaningen af forskelle. Noget af det, mennesker i enhver gruppe har tilfælles, er netop anerkendelsen af andre grupper eller kategorier, som de adskiller sig fra. Det kan ikke være anderledes. Everett Hughes forstod dette i slutningen af 1940'erne, og Fredrik Barth videreudviklede ideen i 1960'erne (Hughes 1994, 91-96; Barth 1969). Men at erkende dette er meget langt fra at være fortaler for, at forskel alene - eller endog i væsentlig grad - er den primære faktor til bestemmelse af identitet. Sådan fungerer den menneskelige verden ganske enkelt ikke.

Ved at se dette forbehold fra en anden vinkel kommer jeg til det tilsyneladende historisk nye eller moderne ved mangfoldighed og forskel. Hvis vi igen betragter Kathryn 
Woodwards citat, som tidligere eksemplificerede denne påstand, synes hendes argument at være: At identiteter i nutiden kommer fra et væld af kilder; at der kan opstå konflikter mellem disse identiteter; at mennesker kan opleve deres identiteter som modstridende og fragmentariske; og at dette historisk set er noget nyt, enten absolut eller til en vis grad.

Hvilket belæg støtter dette historisk nye ved enten mangfoldighed eller identifikationens flerhed? Apropos kulturel mangfoldighed er menneskehedens historie, så vidt den er tilgængelig for os, ikke andet end en historie om vidtgående kulturel mangfoldighed en historie om mennesker med forskellige etniske identifikationer, der møder hinanden, lever side om side, blander sig under forskellige omstændigheder, danner nye identiteter, modsætter sig at blive indlemmet osv. Diaspora og migration er ikke nye fænomener, ej heller er mangfoldighed. Dette er den umiskendelige konklusion, der kan udledes af de arkæologiske og historiske vidnesbyrd (Jones 1997; Llobera 1994; Smith 1986). Apropos andre former for mangfoldighed, så er det, som vi i dag kalder 'seksualitet', 'handicap' osv., heller ikke nødvendigvis klart moderne konstruktioner, selv om de, som det kunne forventes, har deres klart moderne og meget stærke versioner eller udtryk (mht. handicap, se Davis 1997, 9-150; Garland 1995).

Det kan godt være, at globalisering - som jeg anser for at indebære en række reelle forandringer, dog med dybere historiske rødder end ofte antaget - har haft en indvirkning på alt dette. På grund af den øgede hastighed, hvormed vi kommunikerer og bevæger os, er der i dag et større udbud af kulturelle muligheder og kulturel differentiering. Dette er forholdsvis oplagt. Men der er dog to grunde til at frygte, at en accept af dette ikke vil have nogen særlig relevans her.

For det første siger det ikke noget om betydningen af mangfoldighed tidligere sammenlignet med betydningen af mangfoldighed $n u$. Der er al mulig grund til at tro, at mangfoldighed tidligere såvel som nu havde og har en bred vifte af erfaringsmæssige indvirkninger og betydninger for menneskers liv afhængigt af deres historiske, lokale og personlige omstændigheder. Mangfoldighedens enkle kendsgerning er i sig selv muligvis meningsløs, da mere eller mindre af den muligvis hverken er at finde her eller der.

For det andet er et af de vedvarende temaer i den litteratur, der behandler globalisering, at globalisering ikke blot afføder mangfoldighed, men også større kulturel homogenitet og ensartethed. En version af denne tese er blevet berømt i George Ritzers arbejde som McDonaldiseringen af samfundet (1993) og på trods af den kritik, der kan rettes herimod (Smart 1999), er der noget selvfølgeligt over det, som taler på en levende måde til en udbredt livserfaring i begyndelsen af det 21. århundrede. Men homogenitet er måske heller ikke helt, hvad det ser ud til. Som Ulf Hannerz (1992) og andre har argumenteret for, så fremkalder homogenisering eller globalisering - det være sig økonomisk, politisk eller kulturelt - ofte en lokal respons, som på alle måder og af mange forskellige årsager igen lægger vægt på og atter skaber forestillinger om forskellighed og mangfoldighed. Der er tale om en 'glokalisering' - for at låne et moderne ord fra den internationale forretningsterminologi (jf. Robertson 1995). Det globale og det lokale er altid i samme båd, og det samme gælder lighed og forskel. 
Hvis der ikke er noget nyt i mangfoldighed, hvad så med fragmentering og modsigelse? Hvis Woodward med disse begreber mener, at mennesker identificeres på mange forskellige måder, som ikke altid passer godt sammen, hvilket medfører personlige problemer og offentlige anliggender, som de og andre skal forholde sig til, så synes argumentet for begrebernes historiske nyhed i bedste fald ikke at være bevist. Den store og gamle verdenslitteratur antyder, at der ikke er noget nyt i, at man beskæftiger sig med og taler om disse emner. For nu at gribe til en etnocentrisk kilde, der forråder min metodistiske opdragelse, så er den kristne bibel fyldt med eksempler på den slags emner og problemer. Et af dem er Det Gamle Testamentes fortælling om Josef i Egypten. Et andet er lignelsen om den barmhjertige samaritaner (Luk 10, 25-37) med dens sigende svar på spørgsmålet: 'Hvem er min næste?'. Hvad handler denne fortælling om? Hvad er dens relevans her? Det centrale spørgsmål er interessant i sig selv. Det stammer fra et tidligere spørgsmål fra, naturligvis, en lovkyndig: "Hvad skal jeg gøre for at få evigt liv?” Hertil siges Jesus at have givet to bud, af hvilke det andet er, at “du skal elske din næste som dig selv”. Den lovkyndige, som straks får øje på problemet, beder om en uddybning: “Hvem er så min næste?” Og det er et svært spørgsmål.

Svaret er fortællingen om en mand, som vi (ligesom tilhørerne) antager er jøde, og som var på vej fra Jerusalem ned til Jeriko og faldt i hænderne på røvere. Som han lå der i vejkanten, nøgen og såret, kom først en præst og derefter en levit - en anden religiøs specialist - ham i møde, men de gik videre, over på den anden side og lod ham ligge. Endelig kom en samaritaner hen til ham, forbandt hans sår, løftede ham op på sit ridedyr og bragte ham til et herberg. Næste morgen lod samaritaneren ham blive der, så han kunne komme sig, og betalte hans regning forud. Da den pinligt berørte lovkyndige blev spurgt om, hvem af disse tre, der var offerets næste, indså han, at det var samaritaneren, som havde vist ham barmhjertighed.

Det vigtige ved denne fortælling om den barmhjertige samaritaner er ikke, om den er 'sand' eller ej. Det vigtige er, at lighed og forskel udgjorde et problem og blev diskuteret for næsten totusinde år siden. Om ikke andet så vil fortællingen altid vække stor genklang. Ikke alene har den barmhjertige samaritaner vundet indpas i daglig tale, men, som man måske kunne forvente, har den affødt et væld af eksegetisk-teologisk litteratur (som jeg ikke vil inddrage, da jeg ikke er teolog). Men til vort formål henviser spørgsmålet 'Hvem er min næste?' os desuden til sociologiske spørgsmål om identitet. Præsten og levitten, som er jøder, har samme etniske baggrund som ofret for røverne og som tilhørerne. Dog viser deres modstand mod - eller deres manglende evne til, måske på grund af en risiko for rituel urenhed - at tage imod ham som en ligestillet samtidig en række tegn på differentiering. De har uden tvivl takket Gud for, at de ikke var som andre mennesker. Samaritaneren derimod, som ikke blot havde en anden etnisk baggrund, men som også ifølge lokal sprogbrug var fjenden, er i stand til at gøre netop det: At anerkende det, som han har til fælles med en nøgen og såret jøde, nemlig det at være en medrejsende og være et medmenneske. Identitet er altid - har altid været - et spørgsmål om lighed og forskel, og der er altid mulighed for diskussion: Intet er givet eller nødvendigvis forudsigeligt. Hvem der er min næste afhænger af processen, af hvad folk gør. Det er ikke en formel, fast følgevirkning af nominel identifikation. 
Der er en sidste grund til at være dybt mistænksom over for disse påstande om det historisk nye ved forskel og dens fordele eller ulemper. De har en familielighed med andre påstande om det nye - i og om den højere og raffinerede visdom - lige nu og her. Blandt de aspekter af det sociale liv, som synes at være klart moderne, hører barndom, refleksiv selvidentitet og privatliv. Antropologen i mig må her insistere på, at sådanne argumenter fortæller mere om forfatternes etnocentrisme og komparative, etnografiske uvidenhed end om noget andet (og det er før, vi kommer til deres forståelse af historie). Dog tror jeg, at det, som de faktisk fortæller os om, er modernitetens indbildskhed og tilbøjeligheden til - selv blandt dem, som identificerer sig med postmodernismen - at se fortiden som blot et venteværelse til og en forberedelse til nutiden. Historisme er en stærk fristelse, hvilket behændigt bringer mig videre til min sidste grund til at tage afstand fra en identitetsmodel, der lægger vægt på forskel.

\section{Tredje forbehold}

Et fokus på forskel gør det umuligt at beskæftige sig med samfundsteoriens vigtigste spørgsmål eller måske overhovedet at anvende samfundsteori. Efter min mening er de vigtigste spørgsmål, som samfundsteorien bestandigt bringer på bane: 'Hvordan skal man forstå samfundsmæssige forandringer?' Og 'hvordan skal man forstå forholdet mellem individet og kollektivet?’. Disse spørgsmål hænger naturligvis sammen.

At fokusere på forskel er efter min mening nytteløst, hvis man ønsker at forstå samfundsmæssige forandringer, og af de samme grunde, som jeg allerede har givet for at afskaffe modellen for identitet-som-forskel. Den synes ikke at være i overensstemmelse med de observerbare realiteter. For at sige det helt enkelt er kollektiv mobilisering i forfølgelse af fælles mål et sine qua non i historisk og samfundsmæssig forandring. Det er ikke det eneste vigtige, der sker, men det er der, uanset hvor man kigger hen. For mig at se indebærer det nødvendigvis kollektive forestillinger om lighed såvel som forskel (med al respekt for Marx og Simmel, citeret tidligere). For at uddybe dette nærmere kan man i det mindste til en vis grad forstå den sociale forandrings konsekvenser og processer ved at se på samspillet i forholdene mellem lighed og forskel - hvilket Durkheim havde en klar forståelse for i The Division of Labour.

Apropos forholdet mellem individet og det kollektive, så er problemet endnu mere fundamentalt og endnu lettere at fremstille. Jeg er ikke sikker på, om det overhovedet er muligt at have nogen model for det sociale livs kollektive dimensioner - andet end på en ren adderende, aritmetisk måde - på basis af en model for identitet og identifikation, der lægger vægt på forskel. Hvis identitet i væsentlig grad eller bare i det store hele er et spørgsmål om fission og eksklusion, hvor kommer så det mere-end-summen-af-delene fra, som er det vedvarende mysterium i menneskers almindelige dagligdag og i det kollektive? Mens det er interessant at se, at alle britiske samfundsteoretikere, som jeg har nævnt, rutinemæssigt, og det skal de naturligvis, udfolder begreber om det kollektive, om det sociale og om samfundet - skønt man ikke kan sige det samme om deres inspiratorer såsom Derrida og Lacan, og skønt det ej heller kommer klart til syne hos Butler - 
så viser disse begreber sig ofte at være i modstrid med deres identitetsmodeller og passer faktisk ikke rigtigt sammen med dem.

Men der er også en mere generel pointe at fremføre om teori. Al slags teori afhænger af tre forbundne processer: Abstraktion, generalisering og sammenligning. Samfundsteori er ingen undtagelse. En model for den sociale verden, som er dannet på grundlag af identitet og identifikation, levner yderst begrænset plads til generalisering og i særdeleshed sammenligning. Selv nogle af de forfattere, som stadig argumenterer for brugbarheden af forskel som et alenestående begreb for identitetsforståelse, synes at være begyndt at indse dette. Således senest udtrykt af Floya Anthias:

One of the dangers of focusing on difference may be a retreat into empiricism. For the very assertion of the existence of difference involves taking at face value the appearance of living in a diverse and fragmented universe. There is a failure to interrogate what may lie behind or beneath these surface appearances, to find connections and commonalities. $(1998,509)$

Apropos empirisme, så tror jeg, at Anthias har ret, skønt hun sandsynligvis undervurderer tilfældet. I parentes bemærket kan dette problem måske hjælpe med at forklare, hvorfor den litteratur, som jeg har henvist til, så sjældent er baseret på systematiske undersøgelser, på streng empirisk forskning; hvorfor så meget af det, der påkalder sig forskning, afhænger af let deskriptive, etnografiske eller på anden måde kvalitative beskrivelser; hvorfor essayet som genre dominerer; hvorfor så meget af det præsenteres som diskussioner omkring emner snarere end om dem. Måske er det den eneste måde, hvorpå man kan skjule og holde denne empiricisme og non-teori i skak.

\section{Ikke blot et spørgsmål om teori}

Som jeg argumenterede for tidligere, bunder 'forskelsparadigmet' i en genopstilling og reorientering af venstrefløjens politik. Det er lettere at forstå og sympatisere med, når man ser det fra følgende synspunkt: Det var et svar, der passede til den tid. Men tiderne skifter. Så jeg vil runde af med en kort politisk pointe. Som med så meget andet, som jeg har skrevet i denne artikel, gør jeg ikke krav på slående originalitet.

En af de politiske impulser, der står bag understregningen af forskel, er en bøn ikke kun om at tolerere forskel, men om entusiastisk at tage imod den med åbne arme. Jeffrey Weeks har udtrykt dette i forbindelse med argumentet om, at forskel historisk set er noget relativt nyt:

If ever-growing social complexity, cultural diversity and a proliferation of identities are indeed a mark of the postmodern world, then all the appeals to our common interest as humans will be as naught unless we can at the same time learn to live with difference. $(1990,92)$

Vi er tilbage ved Charles Taylors anerkendelsespolitik. Dette er faktisk en kalden til kamp på pluralismens vegne, hvad enten det er i dens liberale eller mere radikale ver- 
sioner. Dette er fint og svært ikke at være enig i. Der er tale om argumenter og værdier, som skal forsvares, plejes og støttes. I lige så høj grad nu som for halvtreds eller hundrede år siden.

Men det alene gør det ikke. Der er stadig presserende, politiske emner, som simpelthen ikke kan klares ved at fremhæve det positive ved forskel eller ved at argumentere for tolerance og pluralisme. Blandt andet handler disse emner om kollektivt tilhørsforhold, om kollektiv ulempe og ikke mindst om forholdet mellem på den ene side friheden til at være forskellig og på den anden side lighed og kollektiv ansvarlighed. At behandle disse emner - som hverken er nye eller enkle - kræver en identitetsmodel, som sætter lighed og forskel i midten og på lige fod med hinanden. Selv om det ikke for at gentage Bauman $(1999,190)$ er tid til at 'hidkalde universalismen fra dens eksil' - og i hvert fald ikke en universalisme i dens oprindelige form - er det måske tid til at vende tilbage til en politik, som anerkender andre svar på kollektive dårligdomme end de rent privatiserede og individualiserede.

Med andre ord er det tid til ikke at tale om forskel. Det er tid til at tale om lighed og forskel ikke blot som forbundne størrelser, men som uløseligt sammenfiltrede, som noget vi kun kan tale om i et og samme åndedrag.

\section{Litteratur}

ANTHIAS, F.

1998 "Rethinking social divisions: some notes towards a theoretical framework", Sociological Review 46, 505-35.

BARTH, F., ed.

1969 Ethnic Groups and Boundaries: The Social Organisation of Culture Difference, Oslo.

BAUMAN, Z.

1990 Thinking Sociologically, Oxford.

1992 “Soil, blood and identity”, Sociological Review 40, 675-701.

1999 In Search of Politics, Cambridge.

BENHABIB, S.

1996 "Introduction: The Democratic Moment and the Problem Of Difference", S. Benhabib, ed., Democracy and Difference: Contesting the Boundaries of the Political, Princeton.

BUTLER, J.

1990 Gender Trouble: Feminism and the Subversion of Identity, New York.

ClARKE, J. og E. SARAGA

1998 “Introduction”, E. Saraga, ed., Embodying the Social: Constructions of Difference, London.

DAVIS, L. J., ed.

1997 The Disability Studies Reader, New York.

GARLAND, R.

1995 The Eye of the Beholder: Deformity and Disability in the Graeco-Roman World, London.

GILROY, P.

1997 “Diaspora and the Detours of Identity”, K. Woodward, ed., Identity and Difference, London.

GutMann, A. 
1994 “Introduction”, i A. Gutmann, ed., Multiculturalism: Examining the Politics of Recognition, Princeton.

HALL, S.

1992 “Our Mongrel Selves”, New Statesman and Society, supplement, 19 June 1992, s. 6-8.

1996 “Introduction: Who Needs Identity?”, S. Hall and P. du Gay, eds., Questions of Cultural Identity, London.

HANNERZ, U.

1992 Cultural Complexity: Studies in the Social Organization of Meaning, New York.

Hughes, E. C.

1994 On Work, Race and the Sociological Imagination, L. A. Coser, ed., Chicago.

IRIGARAY, L.

1993 Je, tu, nous: Towards a Culture of Difference, trans. A. Martin, New York.

JONES, S.

1997 The Archaeology of Ethnicity: Constructing Identities in the Past and Present, London.

LLOBERA, J.

1994 The God of Modernity: The Development of Nationalism in Western Europe, Oxford.

RITZER, G.

1993 The McDonaldization of Society, Pine Forge.

ROBERTSON, R.

1995 "Glocalization: Time-Space and Homogeneity-Heterogeneity”, M. Featherstone, S. Lash and R. Robertson, eds., Global Modernities, London.

SEIDMAN, S.

1997 Difference Troubles: Queering Social Theory and Sexual Politics, Cambridge.

SIMMEL, G.

1950 The Sociology of Georg Simmel, K.H. Wolff, ed., New York.

SMART, B., ed.

1999 Resisting McDonaldization, London.

SMITH, A. D.

1986 The Ethnic Origins of Nations, Oxford.

TAYLOR, C.

1994 "The Politics of Recognition”, A. Gutmann, ed., Multiculturalism: Examining the Politics of Recognition, Princeton.

TAYLOR, D.

1998 "Identity and Social Policy: Engagements with Postmodern Theory", Journal of Social Policy, vol. 27, 329-50.

WEEKS, J.

1990 "The Value of Difference, J. Rutherford, ed., Identity: Community, Culture, Difference, London.

WHEEN, F.

1999 Karl Marx, London.

WOODWARD, K.

1997 “Concepts of Identity and Difference”, K. Woodward, ed., Identity and Difference, London.

\section{Summary}


This paper outlines the currently-dominant 'difference paradigm' in the study of social identity, and argues that, for three reasons, it is time to move on. First, to concentrate on difference makes it impossible to understand what identity is and how it works. Second, to concentrate on difference is to fly in the face of the observable realities of everyday human life. Third, to concentrate on difference makes it impossible to deal with the core questions of social theory, or even, perhaps, to engage in social theory at all. It is proposed that a model of identification as simultaneously a matter of similarity and difference is required if these criticisms are to be met.

Richard Jenkins

Professor

Department of Sociological Studies

University of Sheffield 
